\title{
THE PLIGHT OF THE CHINESE SIKAS
}

\section{By Ricirard Glover}

Some readers may be surprised to find Oryx printing an article on the sika deer. They know the animal so well as an ornament of many British parks, and as an escaped immigrant which has established itself with remarkable success in many English, Scottish, and Irish woodlands. But the animal of which they are thinking is the Japanese sika. This is only one, and that the smallest and least impressive, of a number of deer which, perhaps mistakenly, are usually regarded as local races of a single, very variable species. For China, as well as Japan, is the home of sika. The Chinese sikas range from the forests of tropical Formosa to the northern snows of East Siberia, beyond China's own boundarics. Among them are found by far the finest deer of the sika type and there is not one of them whose present status should not cause anxiety.

The races of silka found in Chinese (including Manchurian) territory are the subject of some difference of opinion but, in spite of a recent and valuable publication, I think Arthur Sowerby's older classification still fits the facts best. I therefore list :-

(1) In the N.I. corner of Korea, and thence northward through S.E. Manchuria, down the Ussuri valley and far into the Maritime Province of Siberia, the Ussurian sika or Dybowski's dcer, Crrous nippon dybozuskii, Taczanowski. ('This is Lydekkcr's Pekin sika, Cervus n. hortulorum.)

(2) In Quelpart Island, the main part of Korea, and thence westward through central and southern Manchuria, the MIanchurian sika, $C$. n. mantchuricus, Swinhoc.

(3) In Chihli province, the North China sika, C. n. mandarinus, Milne-Edwards.

(4) In Shansi, the Shansi sika, C. in. grassianus, Heade.

(5) South-westward from Nanking, Shanghai, and Hangchow, the South China sika, C. n. kopschi, Swinhoe.

(C) The island race, the Formosan sika, C. n. taiouamus, Blyth.

Those who have seen only the small and stocky Japanese sikn can have little iden what fine animals these Chinese sikas are. 'The first four races are big decr, standing up to 42 inches high at the shoulder and hence comparable to the average Scottish red deer. The Ussurian and Mnnchurian sikas differ in certain markings about the head, but still share the characters of being brilliantly spotted in summer, and losing most of their spots in 
winter, whereas mandarinus remains well spotted at all seasons, and grassianus is hardly spotted at any season. The South China sika is a little fellow, scarcely larger than the Japanese but, unlike the Japanese and like mandarinus, it too retains its spots at all scasons. So also does the Formosan sika; but, for an island race, this deer reaches an unexpected size, smaller indeed than the four big northern races, but markedly greater than the Japanese sika. Very few, if any, deer exceed the Formosan sika in beauty. A character, in which all Chinese sikas seem to differ from the Japanese, is the colour of the velvet on the stag's growing antlers. This is red, at least in the Ussurian, Formosan and South China races and, most probably, in the Manchurian race; whereas in those Japanese sikas, whose velvet I have noticed, the colour has been a greyish black to black.

In Britain the feral Japanese sika has made itself more familiar than welcome to professional foresters. Thereby it reflects the habits of its Chinese relatives. Nearly a century ago, that great discoverer of so much of China's wonderful fauna, the British consul Robert Swinhoc, found the home of the Formosan sika in "the central or higher range of mountains, which are in parts covered with perennial snow ... [and] abound in large masses of tangled forest" (1862, p. 303). "Heavily forested country" is likewise the home of the South China sika, according to G. M. Allen (1940, I, p. 1190). Sowerby found grassianus " confined to the forested and mountainous part of Shansi that lies west of the Fen Ho" (1918, p. 119), and in Manchuria he reported the native sika as dwelling "in the depth of the Kirin and Heilungkiang forests" (1923, I, p. 133). Lydekker also says that forests are the home of Dybowski's decr (1898, p. 120).

Everywhere, then, the sika deer are woodland beasts. And that is one reason for anxicty about their future. In China wood is something everyone needs, yet before the Communists took over, almost no one saw any occasion to plant trees. 'Traveller after traveller bears witness to the wholesale destruction of China's magnificent forests in this century; and no creaturc can survive the destruction of its habitat.

But this is not the only reason for anxicty about the sika decr of China. He is also a beast with a price upon his head. Chinese medicine has long regarded a preparation of decr's antlers as a cure for what Swinhoe calls "debility"-but meaning, apparently, impotence. 'The stag's antlers are cut off a little before they are quite fully grown; then according to Swinhoe's recipe, the velvet is stripped off, " the horn is dried, pared thin with an instrument like a nutmeg grater, and boiled in soup, in 
EAST CHINA.

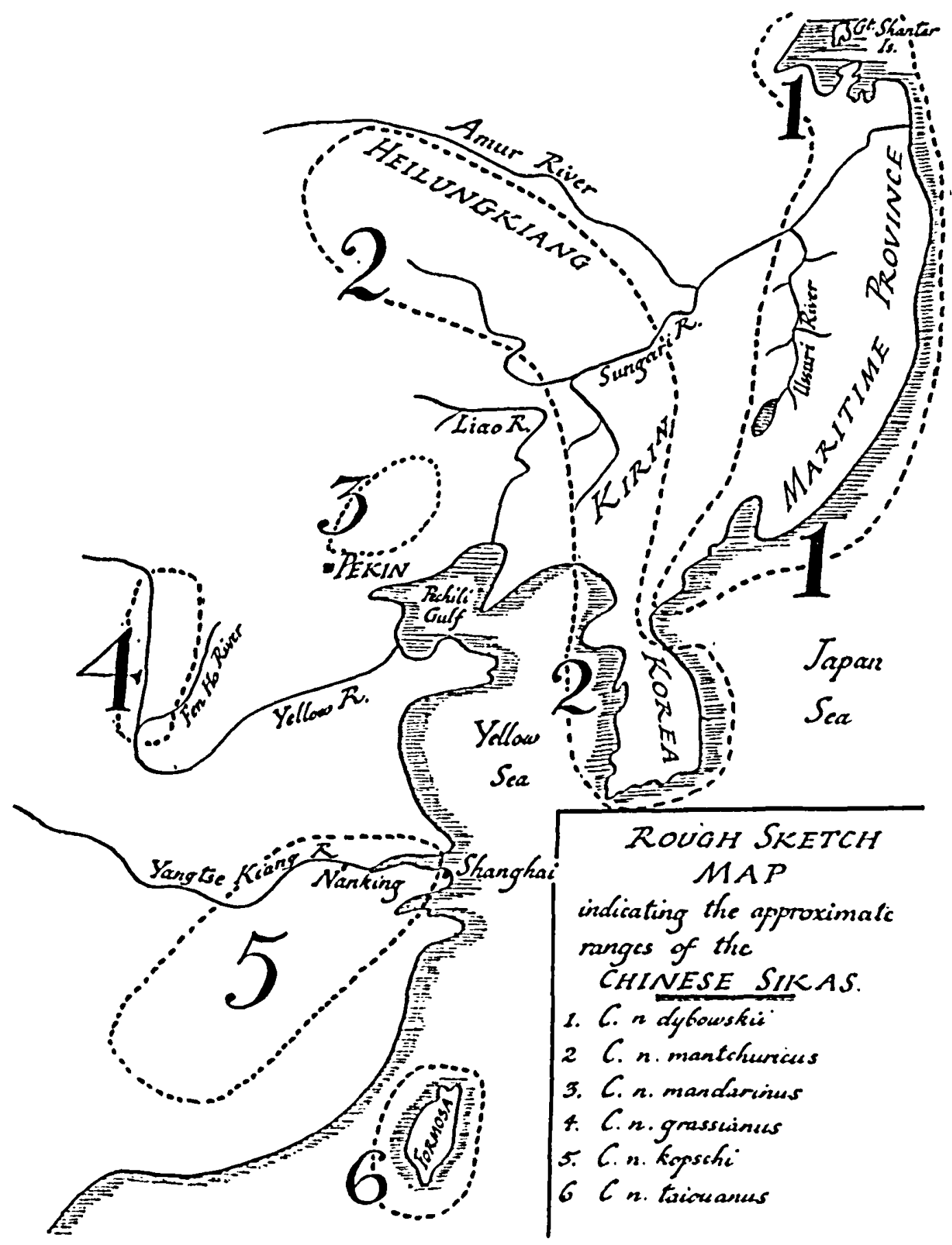

which state it is used. The velvet is not wasted, but is set aside to deal out in small quantities to matrons of the family to aid them in convaleseence after child-birth " (1862, pp. 362-3).

Whether these prescriptions can have any medicinal effect is a question for a doctor, but there is no doubt about their 
economic effects. Half a century ago the Russian traveller, Prince Demidoff, found that, beyond China's borders, the Altai wapiti (or " maral") was being farmed simply for the sale of its antlers on the Chinese market. " An average head," he wrote, fetches from 100 to 120 roubles ( $£ 10$ to $£ 12) "(1900$, pp. 54-55). In Kansu a dozen years later Frank Wallace found wapiti scarce and much hunted, for the price of their antlers was some $£ 7$ to f8 a head-a smaller price, but then the Kansu stag does not grow so fine a head as the Altai. Similarly, wherever antlered deer exist in China, they are all tirelessly pursued, but it is the sika's misfortune that its antlers are supposed to make better medicine than any other deer's. So in 1913 Sowerby found


(1923, I, p. 133), and in 1929 he reported that the South China

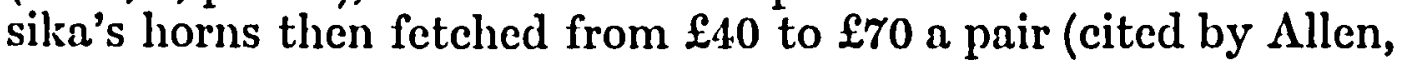
1940, II, p. 1190).

The persistent hunting that results from such prices might do little harm if it were only done by stalking stags with a rifle, but the Chinaman makes free use of set-guns, snares and pitfalls also. The destruction of the deer themselves goes hand-in-hand with the destruction of their habitat; and the methods of slaughter used spare neither hind nor calf.

It is not surprising that animals harried in this fashion should grow rare. MIy friend, G. IK. Whitchead, tells me that the Formosan sika, for long protected by the Japanese, has already declined nearly to extinction in the few years since Japanese rule of Formosa ended. The South China sika may do somewhat better. It has a larger range and is a smaller animal, capable of concealing itself more suceessfully in less cover; but when G. M. Allen surveyed its status in 1940, it was already " rare in the Yangtze valley", and not noticeably common anywhere elsc. Of the more northern races, Sowerby wrote in 1918 " unless immediate and very practical steps are taken, both $C$. grassianus and $C$. mandarinus will become extinet". Both may be lost by now.

In 1923 Sowerby described the Manchurian sika as " diminished in the wild state to a point bordering on extinction " in Chinese territory and concluded that its best hope of survival lay in a semi-domestic existence on decr-farms. Of the Ussurian sika K. Abramov stated in 1930 that it was "rapidly disappearing " as a wild animal in Russian territory, though at that date 117 decr-farms maintained some 1,700 head. In Korea, according to Sowerby, sikas still flourished in the 1920s, but they did so as a result of Japancse protection. They have now been 
denied that protection for as long as the unfortunate Formosan sika.

On cvery count there are grounds for pessimism over the future of China's sikas, even without wcighing the effects of Mao-tse-tung's Communist revolution. When that revolution is considered, the situation must be reckoned blacker still. As long as the Chinese druggists demand for antler powder made it profitable to kecp deer for the purpose of cutting off the stag's horns every August, decr were bred on many farms inside and outside China, those farms offered the best hope for the survival of the Manchurian and Ussurian sikas. But it was in "rich Chinese families ", as Prince Demidoff wrote long ago, that every good dowry contained "maral-horn powder". The rich Chinese are the very ones whom the Communists have liquidated and it seems likely that the market they created for the antlers of farmbred deer died with them; but presumably the more plebeian market for the meat and hides of wild decr will continue.

In such a situation as this, it would seem only realistic to regard the Chinese sikas as having joined that group of animals -the European bison, Père David's decr, Mongolian wild horse and Hawain goose-whose survival depends upon their most careful management in parks and zoos outside their native habitat. Happily, there do exist some stocks of Chinese sikas that can be preserved in this fashion. There is a fine herd of Formosan sikas kept apart in a special paddock at Woburn, and smaller herds at Whipsnade, the Chessington zoo and the Bronx zoo in New York. MIoreover, Mr. Whitehend tells me, there is a small herd of Formosan sika in Japan, running loose on an islet near Tokyo. Of the Ussurian sikn, or Dybowski's clecr, at least two small herds exist in America, at the Bronx zoo and the Catskill game farm. 'There is another at the Frankfurt zoo in Germany (a country where there may ensily be more, for the Berlin zoo once maintained a considerable stock derived from Great Shantar Island in the Okhotsk Sea). At Woburn there is also a herd of sika commonly called " Manchurian ", an offshoot of which runs free in the North Island of New Zealand, but it is doubtful how far these animals deserve that name. Sika interbreed very readily and as a varicty of races were turned loose together in Woburn park in the 1890s (Loisel, 1907, p. 424), these "Nanchurians" are almost certainly of mixed blood. In the present scarcity of purebred stock, however, they remain valuable as fine examples of the general large sika type.

In conclusion, conservationists can only hope that owners of these stocks of Chinese sika will appreciate their unusual interest. 
If they were allowed to die out, little comfort could be found in the survival of the Japanese races. Rather, it would be a tragedy like, say, the extinction of the Kodiak bear while the common brown bear survived. For the large Chinese sika are to the Japanese much what the Kodiak bear is to the brown-the same general sort of thing, but far more striking and attractive.

\section{BIBLIOGRAPIIY}

AnRamov, K., 1030. "Some Data on Cervus hortulorum in Primor'c (East Siberia)." In Russian. English summary in Biological Abstracts, §30001. Alsen, G. M1., 1040. The Mammals of China and Mongolia. Washington.

Denidofe, Prince Elim Pavlovitcit, 1000. After Wild Sheep in the Allai. London.

Kunods, N., 1030. "The Distribution of Mammals in the Japanese Empire." The Journal of Mammalogy.

Lo1SEL, G., 1007. " The Zoological Gardens and Establishments of Great Britain, Belgium, and Holland." Ann. Rept. Smith. Soc.

LyDeminer, R., 1808. Deer of all Lands. London.

Sowrmmy, A. DE C., 1018. "On the Sika Deer of North China." Ann. \& Mag. of Nat. Il ist.

1023. The Naluralist in Manchuria. Tientsin.

Swinior, Rousent, 1802. "On the Mammals of Formosa." P.Z.S.

Wartace, FranK, 1040. IIunting Winds. London. 